\title{
Nursing intervention: post-operative care with chest tube in adults
}

\author{
Intervenção de enfermagem: cuidados com dreno torácico em adultos no pós-operatório
}

Raquel Constantino de Almeida ${ }^{1}$, Priscilla Alfradique de Souza ${ }^{1}$, Rosimere Ferreira Santana ${ }^{2}$, Aline Affonso Luna ${ }^{1}$

Objective: to validate the nursing activities for intervention established by the Nursing Interventions Classification "chest tube care". Methods: content validation study carried out in two intensive units, in which 30 specialist nurses evaluated each activity belonging to the intervention "chest tube care, according to importance and objectivity. The activities were analyzed through a Likert-type scale to determine the index of content validation and reliability. Results: of the 38 activities that are part of the intervention, thirty-five were considered validated. The three non-validated activities were related to the determination of the indication for chest drain, availability of non-traumatic clamps, and occlusion of the device. Conclusion: based on the analysis of the participating nurses, the intervention could be considered as validated and feasible in the Brazilian care practice in order to facilitate the implementation of systematized care.

Descriptors: Validation Studies; Nursing Process; Perioperative Nursing; Postanesthesia Nursing; Thoracic Surgical Procedures; Drainage.

Objetivo: validar as atividades de enfermagem para intervenção estabelecida pela Nursing Interventions Classification "cuidados com dreno torácico". Métodos: estudo de validação de conteúdo, realizado em duas unidades intensivas, nas quais 30 enfermeiros especialistas avaliaram cada atividade pertencente à intervenção "cuidados com dreno: torácico", conforme importância e objetividade. Atividades analisadas a partir de uma escala de Likert para determinação do índice de validação de conteúdo e confiabilidade. Resultados: das 38 atividades constituintes da intervenção, trinta e cinco foram consideradas validadas. As três atividades não validadas tratavam sobre determinação da indicação para o dreno de tórax, disponibilidade de clampe não traumático e oclusão do dispositivo. Conclusão: a partir da análise dos enfermeiros participantes, a intervenção pôde ser considerada validada e passível de realização na prática assistencial brasileira, de forma a facilitar a realização de cuidado sistematizado.

Descritores: Estudos de Validação; Processo de Enfermagem; Enfermagem Perioperatória; Enfermagem em Pós-Anestésico; Procedimentos Cirúrgicos Torácicos; Drenagem.

\footnotetext{
${ }^{1}$ Universidade do Estado do Rio de Janeiro. Rio de Janeiro, RJ, Brazil.
}

${ }^{3}$ Universidade Federal Fluminense. Niterói, RJ, Brazil. 


\section{Introduction}

After completion of surgical procedures, the client experiences a postoperative phase, one of the most critical moments culminating in high care demands due to the complex emotional, psychological $^{(1)}$ and physical changes that take place in this phase. The complexity of post-surgical critical clients and the interest in defining the tasks of the nurses providing care, especially regarding care with chest drains, make it increasingly necessary to improve the scientific knowledge of nurses in this theme.

Although the insertion of a chest drain is understood to be the responsibility of other health professionals, the nursing team is the main responsible for the management of this device in clients during the immediate and late postoperative period ${ }^{(2)}$. Thus, the nursing team should seek the reduction of complications associated with the use of chest tubes. However, despite this attribution, there is controversy in the literature and little scientific evidence regarding this care $^{(3)}$.

Specific nursing actions must be adequate to the needs identified in postoperative clients. In this phase, adequate conducts based on critical reasoning can be facilitated through the standardization ${ }^{(4)}$, documentation and communication of actions, which occurs through the completion of the nursing process, a mandatory nursing activity composed of five steps, among them the nursing interventions. One of the terminologies used to standardize the interventions performed by nurses is the Nursing Interventions Classification which defines nursing intervention as "any treatment, based on clinical judgment and knowledge, performed by a nurse with the aim to improve patient outcomes"(5:203).

Nursing care is, therefore, based on the nursing process, and this, in turn, uses predetermined scientific interventions in the planning and implementation of nursing care. Currently, there is a specific nursing intervention for chest drain care created by the Nursing Interventions Classification, in 1992, and revised in 2013, entitled "Tube Care: Chest". The definition of this intervention is: "management of a patient with an external water-seal drainage device exiting the chest cavity" $^{\prime(5: 2)}$ and is composed of 38 activities which are considered steps to be performed by nurses during the care practice ${ }^{(5)}$. In order to avoid incorrect manipulation, to normalize the actions during the chest tube care, this intervention of the Nursing Interventions Classification presents essential phases necessary to maintain excellence care as based on scientific evidence.

When considering the aspects addressed, as the following a research question was adopted: what is the validity attributed by nurses to activities developed during chest tube care in postoperative adult patients in intensive care units?

This study is justified by the need to disseminate the knowledge on this theme, given the small number of publications on chest and thoracic tube care in the national and international literature. The manipulation of chest drains is a frequent practice in the postoperative phase of surgeries, such as cardiac and thoracic surgeries. The accuracy in the development of this intervention may help to prevent postoperative complications related to chest tube care and, consequently, reduce hospitalization time and healthcare costs.

Therefore, the aim of the study was to validate the nursing activities for the intervention established by the Nursing Interventions Classification "chest tube care".

\section{Methods}

Content validation study whose scenarios were two intensive care units (General and Cardiac Surgical unit) of a hospital in Rio de Janeiro, RJ, Brazil, belonging to the Sentinela network. At the time of the research, the institution had 18 beds in these units and 48 nurses.

Of the initial number of nurses, eleven did not meet the inclusion criteria: to be a bachelor in nursing, 
to act professionally for at least five years as a nurse, to be a member of the intensive care team, with a year or more of direct work in one of the study scenarios. Of the 37 possible participants, seven were excluded due to discontinuity, one of which changed to another sector during the collection period and six because of vacations. Thus, 30 nurses participated in the study.

The convenience selection method was used to compose the sample, which consisted in a panel of specialists for validation of the intervention ${ }^{(6)}$. The time of clinical performance in the scenario evaluated was used as parameter for the qualification of the ex$\operatorname{perts}^{(7)}$.

Data collection was performed from May to August 2017 through a questionnaire containing open and closed questions. The instrument was delivered to the nurses during their respective work shifts. After explaining the research, clarifying the objectives and reading the informed consent form, the questionnaire was delivered for self-completion and returned according to the participants' availability.

The first part of the instrument covered identification data, sociodemographic aspects and occupational data; the second, addressed guidelines for completing the instrument, definition of the "tube care: chest" intervention and 38 activities related to this nursing intervention proposed by the Nursing Interventions Classification ${ }^{(5)}$. The criteria used to evaluate each activity were relevance and objectivity; they were evaluated in a Likert-type scale, with five response options (None, Little, Moderate, Great, and Total).

In the second part of the instrument, it was indicated in item 32: cleaning around the insertion site the chest tube using saline $0.9 \%$; in item 33: exchange the dressing around the chest tube every 24 hours and as needed; and in item 34 : use of gauze with $0.9 \%$ saline solution for cleaning the insertion site, for drying, followed by use of $70.0 \%$ alcohol and local occlusion with gauze ${ }^{(8)}$.

The following scores were attributed in the
Likert scale: None (value: 0), Little (value: 0.25), Moderate (value: 0.50), Great (value: 0.75 ), and Total (value: 1 ). In order to evaluate each item individually (nursing activity), as well as the whole instrument (nursing intervention "tube care: chest"), Content Validation Index values above 0.75 were considered acceptable $^{(6)}$. The Content Validation Index was used to determine how important and objective the activity was in the study scenarios.

Inferential descriptive statistical analysis was performed by tabulating the data in an Excel spreadsheet (Excel version 2010) and analyzing the data in the Statistical Package for Social Science, version 22.0. To evaluate the reliability of the responses, a Reliability test was applied. For acceptance of the constructs considered valid, we determined the minimum Cronbach's $\alpha$ of 0.70 as acceptable. The analyses were performed considering a maximum significance level of $5 \%(0.05)$.

The research was approved by the Research EthicsCommittee oftheinstitutionaccordingto Opinion no 2,084,762 and CAAE: 67844917.9.0000.5282. The formal requirements contained in regulatory standards for research involving human beings of Resolution 510/2016 and Resolution 466/2012 of the National Health Council were respected.

\section{Results}

The majority of the participants were female $(90.0 \%)$, with a mean age of 41.8 years $( \pm 42.98)$. As for the work sector, the majority (19.3\%) worked in the intensive Cardiac Surgical unit, occupying the position of nurse on call/day care worker (76.7\%). The mean duration of intensive care was 14.5 years $( \pm$ 12.57). Part of the participants (40.0\%) acted as nurses for at least five and 10 years. However, the majority (59.9\%) had more than 11 years of experience in these care settings.

As for academic-professional training, one (3.3\%) nurse had no postgraduate training, and 20 
nurses $(66.7 \%)$ had completed postgraduate training lato sensu (specialization) and nine stricto senso among which seven $(23.3 \%)$ were masters and two (6.7\%) had PhD. Of the 20 (66.7\%) nurses who had postgraduate training lato sensu, 13 (39.3\%) had specialization in intensive care, three $(9.1 \%)$ in medical-surgical specialization, two $(6 \%)$ in cardiology, two $(6.0 \%)$ in hospital administration and one (3.1\%) had residency in Heart Surgery. In addition, 12 (36.3\%) nurses had specialization in topics that were not directly related to the specific area of action in intensive care.

Tables 1 and 2 show the evaluations of the main activities belonging to the Intervention "tube care: chest" of the Nursing Interventions Classification. The values described in descending order represent the extent to which these activities were considered important and objective by the participating nurses. The separation in two tables occurred in descending order of the mean of importance and objectivity. Table 1 shows the activities that presented Content Validation Index $>0.85$.

The activities showed in Table 1 presented an average Content Validation Index $\geq 0.75$. They were therefore considered important and objective by the participating nurses. The activities that were considered most important and objective were: keeping the water-seal chest drainage below the chest level. and Clamping the tubes whenever the drain vial is positioned above the chest level for long periods, ensuring that the clamp is in place for as short time as possible, both with an average Content Validation Index of 0.97.

Table 1 - Mean of the activities evaluated by the participating nurses regarding importance and objectivity, with a mean of Content Validation $\geq 0.75$

\begin{tabular}{|c|c|c|c|}
\hline Activities & Importance & Objectivity & Mean \\
\hline Keeping the water-seal chest drainage below the chest level. & 0.98 & 0.96 & 0.97 \\
\hline Making sure that the chest drainage device is kept upright. & 0.97 & 0.96 & 0.96 \\
\hline Changing the dressing around the chest drain every 24 hours and as needed & 0.96 & 0.95 & 0.95 \\
\hline Monitoring for signs and symptoms of pneumothorax & 0.97 & 0.87 & 0.92 \\
\hline Supervising for symptoms of troubleshooting of pneumothorax & 0.92 & 0.84 & 0.88 \\
\hline Cleaning around the insertion site of the chest tube using saline $0.9 \%$ & 0.91 & 0.85 & 0.88 \\
\hline $\begin{array}{l}\text { Using gauze with } 0.9 \% \text { saline for cleaning the insertion site, drying and using } 70 \% \text { alcohol and then } \\
\text { occlude the spot with gauze }\end{array}$ & 0.87 & 0.86 & 0.86 \\
\hline Using non-traumatic clamp in the chest tube & 0.86 & 0.77 & 0.82 \\
\hline Monitoring tube positioning through radiography & 0.85 & 0.8 & 0.82 \\
\hline $\begin{array}{l}\text { Replacing the thoracic drainage bottles or the multi-chamber drain device as necessary to prevent } \\
\text { overflow or infection control }\end{array}$ & 0.82 & 0.77 & 0.79 \\
\hline $\begin{array}{l}\text { Performing drain milking only when indicated by the patient's condition or as requested by the } \\
\text { physician }\end{array}$ & 0.83 & 0.75 & 0.79 \\
\hline Guiding the patient and family about proper care of the chest tube & 0.82 & 0.74 & 0.78 \\
\hline
\end{tabular}


Table 2 - Mean of activities related to importance and objectivity with average Content Validation Index $<0.75$

\begin{tabular}{|c|c|c|c|}
\hline Activities & Importance & Objectivity & Mean \\
\hline $\begin{array}{l}\text { Determining the indication for chest tube } \\
\text { (e.g., pneumothorax versus fluid drainage) }\end{array}$ & 0.77 & 0.71 & 0.74 \\
\hline $\begin{array}{l}\text { Ensuring that the non-traumatic chest } \\
\text { clamp is available for any accidental discon- } \\
\text { nection or damage to the drainage system or } \\
\text { damage to the tubes }\end{array}$ & 0.77 & 0.63 & 0.7 \\
\hline $\begin{array}{l}\text { Avoiding the occlusion of the drainage flask } \\
\text { or the device while still attached to the } \\
\text { patient when changing the flasks or devices }\end{array}$ & 0.69 & 0.65 & 0.67 \\
\hline
\end{tabular}

Table 2 shows the activities that were not validated and presented a Content Validation Index $<0.75$ : determining the indication for chest tube (0.74); ensuring that the non-traumatic chest clamp is available for any accidental disconnection or damage to the drainage system or damage to the tubes (0.7) and Avoiding the occlusion of the drainage flask or the device while still attached to the patient when changing the flasks or devices (0.64), activities that were not considered validated by the expert participants.

For the results of the reliability, the Cronbach's $\alpha$ was 0.95 , with a mean value of 0.85 (standard deviation $=0.009$ ), which shows a high reliability in the results validated by the participating nurses.

\section{Discussion}

As a limitation of the study, there is a shortage of national and international scientific literature on nursing care associated with postoperative chest tube care, which is also addressed in the literature ${ }^{(9)}$. This fact may hinder the determination by nurses in clinical practice of care based on scientific evidence, as well as the theoretical-reflexive depth proposed by the article.

The main contribution of the results is the application of the validated intervention in direct care during the care practice. Furthermore, the review of the activities by the specialists provides a consequent improvement in the quality of the nursing care, thus, allowing a greater accuracy in the care promoted to clients using chest tubes.

From the 38 activities addressed in the intervention, thirty-five had a validation index greater than or equal to 0.75 and were considered validated by the participating nurses. Those that presented medium indices will be discussed in more detail.

In surgeries whose postoperative phase requires the use of chest tubes, nurses perform all the care to the clients, including that related to the manipulation of this device. Thus, the well-being and prevention of complications associated with the use of tubes must be sought. The presented results indicate that the activity "Keeping the water-seal chest drainage below the chest level" is presented as a care measure indicated in the literature, with evidence of improvement of the gravitational drainage ${ }^{(10)}$, which corroborates the degree of importance and objectivity demonstrated by the participants.

Concerning the clamping of the drain, it is indicated to perform it when it is known that the tube will be removed, in the determination of air leakage or in the exchange of collection flasks ${ }^{(10-11)}$. The tube should remain closed for as short time as possible, especially if the use of the tube was indicated due to the presence of pneumothorax, because disclamping prevents the occurrence of a new pneumothorax ${ }^{(10)}$, or when the blood is being drained and where clotting could result in a risk of cardiac tamponade ${ }^{(11)}$. Clamping of the tube was also demonstrated in activity, presenting a high validation index.

The three activities related to dressing had an important index of validation, but the ones that dealt with the use of the saline solution had smaller averages because the dressing of the chest tube exclusively with $70 \%$ alcohol is still performed although the National Health Surveillance Agency reaffirms the use of sterile gauze with saline solution to clean the insertion site of closed tubes, using sterile gauze to dry the 
site, or $70 \%$ alcohol, occluding the insertion site at the end with sterile gauze ${ }^{(8)}$.

As for the analysis of the activities that address the signs and symptoms of pneumothorax, the monitoring of their occurrence was considered more important than the supervision of the resolution. This fact may influence the frequency of the activities performed in practice because nurses perform such monitoring, but, the evaluation of the outcome of the intervention is still incipient. We believe that the inclusion of these signs and symptoms in the intervention could offer more safety for the nurses, since the occurrence of this problem could be suspected.

The activities that presented low validation averages according to the specialists were: "Using non-traumatic clamp in the chest tube" and "monitoring tube positioning through radiography". This result can be justified by the scarcity of studies on external clamping and the availability of this type of material in the hospital. Regarding monitoring through image examination, the low score in the importance criterion can be justified by the fact that such activity, in the national scenario, is performed by other professionals of the health team with more knowledge in reading chest radiographies. This aspect could be minimized by carrying out permanent education and implementing protocols for reading images and including nurses in the routine of such activity ${ }^{(12)}$.

The activity that deals with the exchange of chest tube flasks addresses the prevention of infection associated with the device. In a previous study, most interviewees indicated that flasks should be routinely changed for infection control, especially when drainage occurred due to pleural effusion ${ }^{(9)}$. However, in this study, this activity had a low index of validation by the participating nurses. It is emphasized that the frequency and the ideal criteria for exchanges are still controversial $^{(9)}$.

The activity that deals with the milking of drains also had a low index of validation by the participating nurses. This fact does not corroborate na- tional and international practice that recommends milking. However, the performance of this activity is still controversial because there is a risk of damage to adjacent tissues when the chest tube is manipulated $^{(10)}$. There is no scientific evidence to recommend whether or not milking should be performed ${ }^{(12)}$.

The activity that deals with guiding patients and families was considered of little importance and little objective. We believe that this activity is of great importance because in the postoperative context, including the intensive care setting, there must be a preparation for discharge with valorization of family guidance ${ }^{(13)}$.

Regarding activities that did not reach the content validation index and had to be excluded, the activity that dealt with the occlusion of the flask raised doubts among the participants because occlusion is necessary for changing the drainage flasks, although for an extremely short time interval ${ }^{(9)}$. Regarding the indication for use of chest tube, it is observed that this practice is not part of the nursing routine of Brazilian nurses because this activity is performed by other health professionals. The activity "ensuring that the non-traumatic chest clamp is available for any accidental disconnection or damage to the drainage system or damage to the tubes" also addresses the existence of clamps, which are not available in the institution studied.

Although the frequency of activities was not analyzed in this study, we believe that activities evidenced with a low validation index by the participating nurses can culminate in activities that are not valued and are little frequent in the nursing care practice. This is a relevant aspect because it may interfere in the definition of professional assignments of nurses and in the process of systematization of nursing care, representing another obstacle among the many others that make difficult the application of systematized care by nurses inside intensive care units ${ }^{(14-15)}$.

In some respects, the decision-making power of nurses over chest tube care appears to be incipient ${ }^{(14)}$. 
Thus, nurses need to be inserted and trained in the contexts related to care for the patients using chest tubes; the professionals involved in this care should be familiar with the respective clinical indications.

\section{Conclusion}

After the specialists from intensive care unit analyzed the 38 activities attributed by the intervention "tube care: chest" of the Nursing Interventions Classification, thirty-five were validated. Therefore, the intervention can be considered feasible in the Brazilian practice of care, in order to facilitate the implementation of the nursing process, culminating in systematized care.

\section{Collaborations}

Almeida RC and Souza PA contributed to conception and designing, analysis and interpretation of the data and writing of the article. Santana RF and Luna AA collaborated with the relevant critical revision of the intellectual content and final approval of the version to be published.

\section{References}

1. Associação Brasileira de Enfermeiros de Centro Cirúrgico, Recuperação Anestésica e Centro de Material e Esterelização. Diretrizes de práticas em enfermagem cirúrgica e processamento de produtos para saúde. Barueri: Manole; 2017.

2. Cook M, Idzior L, Bena JF, Albert NM. Nurse and patient factors that influence nursing time in chest tube management early after open heart surgery: a descriptive, correlational study. Intensive Crit Care Nurs. 2017; 42:116-21. doi: http://dx.doi. org/10.1016/j.iccn.2017.03.008

3. Filosso PL. Chest drainage management: where are we now? Thorac Surg Clin. 2017; 27(1):9. doi: http://dx.doi.org/10.1016/j.thorsurg.2016.10.001
4. Barbosa AS, Studart RMB. Diagnósticos de enfermagem em pacientes internados em uma unidade de pós-operatório de alta complexidade. Rev Enferm UFPI [Internet]. 2017 [citado 2018 jun. 10]; 6(3):18-23. Disponível em: http://www.ojs.ufpi. br/index.php/reufpi/article/view/5893/pdf

5. Bulechek GM, Butcher HK, Dochterman JM, Wagner CM. Nursing interventions classification (NIC). St. Louis: Mosby Elsevier; 2016.

6. Polit DF, Beck CT. Essentials of nursing research: appraising evidence for nursing practice. Philadelphia: Lippincott Williams \& Wilkins; 2014.

7. Souza PA, Santana RF, Cassiano KM. Differential validation of nursing diagnoses of impaired memory and chronic confusion. Rev Enferm UFPE on line [Internet]. 2015 [cited 2018 June 03]; 9(7):9078-85. Available from: https://periodicos. ufpe.br/revistas/revistaenfermagem/article/ view/10700

8. Agência Nacional de Vigilância Sanitária (BR). Medidas de prevenção de infecção relacionada à assistência à saúde [Internet]. 2017 [citado 2018 jun. 10]. Disponível em: http://portal. anvisa.gov.br/documents/33852/271855/Medidas+de+Prevenção+de+Infecção+Relacionada+à+Assistência+à+Saúde/6b16dab3-6d0c-439 9-9d84-141d2e81c809

9. Lu C, Jin YH, Gao W, Shi YX, Xia X, Sun WX, et al. Variation in nurse self-reported practice of managing chest tubes: A cross-sectional study. J Clin Nurs. 2017; 27(5-6):e1013. doi: https://doi. org/10.1111/jocn.14127

10. Zisis C, Tsirgogianni K, Lazaridis G, Lampaki S, Baka $\mathrm{S}$, Mpoukovinas I, et al. Chest drainage systems in use. Ann Transl Med. 2015; 3(3):43. doi: https:// doi.org/10.3978/j.issn.2305-5839.2015.02.09

11. Karimov JH, Gillinov AM, Schenck L, Cook M, Sweeney DK, Boyle EM, et al. Incidence of chest tube clogging after cardiac surgery: a singlecentre prospective observational study. Eur J Cardiothorac Surg. 2013; 44(6):1029-36. doi: https://doi.org/10.1093/ejcts/ezt140

12. Melo JAC, Gelbcke FL, Huhn A, Vargas MAO. The work process in radiological nursing: invisibility of ionizing radiation. Texto Contexto Enferm. 2015; 24(3):801-8. doi: http://dx.doi. org/10.1590/0104-07072015003130014 
13. Santos ES, Gastaldi AB, Garanhani ML, Montezeli $\mathrm{JH}$. Receptional and education process in health to family members patients boarding in adult ICU. Ciênc Cuid Saúde. 2016; 15(4):639-6. doi: http:// dx.doi.org/10.4025/cienccuidsaude.v15i4.33903

14. Carvalho ACTR, Oliveira KT, Almeida RS, Souza FS, Menezes HF. Reflecting on the practice of nursing care systematization in the intensive care unit. Rev Pesqui Cuid Fundam. 2013; 5(2):372329.doi:http://dx.doi.org/10.9789/2175$5361.2013 \mathrm{v} 5 \mathrm{n} 2 \mathrm{p} 3723$
15. Silva EA, Machado MAA, Ribeiro KR, Shimoda, E. Percepção deenfermeiros quantoà implementação do processo de enfermagem em uma unidade de terapia intensiva adulta do noroeste fluminense. Rev Científ Interdiscip [Internet]. 2014 [citado 2018 jul. 25]; 2(1):64-77. Disponível em: http:// revista.srvroot.com/linkscienceplace/index.php/ linkscienceplace/article/view/25/20 